\title{
Direct Imaging of Titania Nanotubes Located in Mouse Neural Stem Cell Nuclei
}

\author{
Yanli Wang ${ }^{1}$, Jia Wang ${ }^{1}$, Xiaoyong Deng ${ }^{1}$, Jiao Wang ${ }^{2}$, Haifang Wang ${ }^{1}$, Minghong $W^{1}{ }^{1}$, Zheng Jiao ${ }^{1}(\varangle)$, and \\ Yuanfang Liu ${ }^{1,3}(\bowtie)$ \\ ${ }^{1}$ Institute of Nanochemistry and Nanobiology, Shanghai University, Shanghai 200444, China \\ ${ }^{2}$ Institute of Systems Biology, Shanghai University, Shanghai 200444, China \\ ${ }^{3}$ Beijing National Laboratory for Molecular Sciences, Department of Chemical Biology, College of Chemistry and Molecular \\ Engineering, Peking University, Beijing 100871, China
}

Received: 20 March 2009 / Revised: 30 April / Accepted: 2 May 2009

(C)Tsinghua University Press and Springer-Verlag 2009. This article is published with open access at Springerlink.com

\begin{abstract}
Titania nanotubes $\left(\mathrm{TiO}_{2}-\mathrm{NTs}\right)$ are a potential drug vehicle for use in nanomedicine. To this end, a preliminary study of the interaction of a model cell with $\mathrm{TiO}_{2}-\mathrm{NTs}$ has been carried out. $\mathrm{TiO}_{2}-\mathrm{NTs}$ were first conjugated with a fluorescent label, fluorescein isothiocyanate (FITC). FITC-conjugated titania nanotubes $\left(\mathrm{FITC}_{\mathrm{TiO}}-\mathrm{NTs}\right)$ internalized in mouse neural stem cells (NSCs, line C17.2) can be directly imaged by confocal microscopy. The confocal imaging showed that $\mathrm{FITC}-\mathrm{TiO}_{2}-\mathrm{NTs}$ readily entered into the cells. After co-incubation with cells for $24 \mathrm{~h}, \mathrm{FITC}-\mathrm{TiO}_{2}-\mathrm{NTs}$ localized around the cell nucleus without crossing the karyotheca. More interestingly, the nanotubes passed through the karyotheca entering the cell nucleus after co-incubation for $48 \mathrm{~h}$. Atomic force microscopy (AFM) and transmission electron microscopy (TEM) were also employed in tracking the nanotubes in the cell. These results will be of benefit in future studies of $\mathrm{TiO}_{2}-\mathrm{NTs}$ for use as a drug vehicle, particularly for DNA-targeting drugs.
\end{abstract}

\section{KEYWORDS}

Titania nanotubes, mouse neural stem cells, nucleus, confocal imaging, atomic force microscopy

\section{Introduction}

It is predicted that nanotechnology has the potential to revolutionize cancer diagnosis and therapy [1-3]. Nanoparticles (NPs) possessing special characteristics can carry multiple therapeutic drugs and imaging agents to a tumor site [4-8]. Several therapeutic nanocarriers have already been approved for clinical trials and use. A particularly desirable target of the drug nanovehicle is the cellular nucleus, in which the most important genetic information DNA is concentrated, enabling some DNA-targeting drugs to kill tumor cells via DNA impairment.

In 2004, Pantarotto et al. functionalized carbon nanotubes with fluorescein isothiocyanate (FITC) and demonstrated by using confocal microscopy that functionalized carbon nanotubes (CNTs) were able to cross the cell membrane and accumulate

Address correspondence to Yuanfang Liu, yliu@pku.edu.cn; Zheng Jiao, zjiao@shu.edu.cn 
in the cytoplasm or reach the nucleus [9]. In 2007, Porter et al. showed by using transmission electron microscopy (TEM) that single-walled CNTs entered the cytoplasm and localized within the cell nucleus [10]. Oyelere et al. demonstrated that gold nanorods conjugated directly to an SV40 virus nuclear localization signal (NLS) peptide could efficiently enter cells, and then translocate to both the cytoplasm and the nucleus portion [11].

To date, utilizing NPs to target the nucleus has not proved very successful due to the poor permeability of the nuclear membranes. Thus, design and synthesis of appropriate drug carriers capable of entering the cell nucleus are imperative. Nano titania $\left(\mathrm{TiO}_{2}\right)$ is biocompatibile and has diverse uses in molecular biology [12-15]. Guzman et al. [16] used $\mathrm{TiO}_{2} \mathrm{NPs}$ to label human central nervous system (CNS) stem cells in transplantation for noninvasive monitoring. Their results indicated that cells labeled with NPs survived longer in a site-specific manner, differentiating them from the unlabeled cells, suggesting that $\mathrm{TiO}_{2}-\mathrm{NTs}$ are a promising drug delivery vector after the surface has been specifically functionalized.

Herein, we present a labeling approach using $\mathrm{TiO}_{2}-\mathrm{NTs}$ conjugated with FITC. FITC-conjugated titania nanotubes (FITC-TiO $-\mathrm{NTs}$ ) can be observed by using confocal microscopy, with one direct-viewing observation for the internalization and translocation of titania nanotubes. Notably, by means of confocal microscopy together with TEM and atomic force microscopy (AFM), we have found that $\mathrm{TiO}_{2}$-NTs can cross the karyotheca and enter the nucleus of mouse neural stem cells.

\section{Experimental}

\subsection{Materials}

All chemicals were commercially available. Ethanol and $\mathrm{NH}_{4} \mathrm{OH}$ were supplied by Sinopharm Chemical Reagent Co. Ltd., China. Tetraethoxysilane (TEOS), (3-aminopropyl)triethoxysilane (APTS), and FITC were purchased from Sigma Aldrich. The fluorescent dye FM4-64 (N-(3-triethylammoniumpropyl)-4-( $p$ diethylaminophenylhexatrienyl)-pyridinium $2 \mathrm{Br}$ ) was obtained from Invitrogen Corp. 4,6-Diamidino- 2-phenylindole (DAPI) and KeyGen nuclei isolation kit were purchased from Nanjing KeyGen Biotech Co. Ltd., China. Standard solutions of titanium were purchased from Shanghai Institute of Measurement and Testing Technology. Dulbecco's Modified Eagle's Medium (DMEM), fetal bovine serum, and horse serum were purchased from Hyclone. Mouse neural stem cells (NSCs, line C17.2) were provided by Dr. E. Snyder of Harvard Medical School, USA.

\subsection{FITC modified nanotubes}

The $\mathrm{TiO}_{2}-\mathrm{NT}$ sample was given as a courtesy by Suzhou Institute of Nano-tech and Nano-bionics, Chinese Academy of Sciences (CAS). The synthesis process was according to Kasuga et al. [17-19]. Briefly, $\mathrm{TiO}_{2}$ powders were prepared by the sol-gel method. The ultrasonic pretreated $\mathrm{TiO}_{2}$ powder $(200 \mathrm{mg})$ was dispersed in $140 \mathrm{~mL}$ of $10 \mathrm{~mol} / \mathrm{L} \mathrm{NaOH}$ solution. The solution was heated to $130{ }^{\circ} \mathrm{C}$ for $35 \mathrm{~h}$ in an oven and then cooled naturally in air. Next, the solution was centrifuged at a $8000 \mathrm{rpm}$ and the precipitate was collected. Finally, after carrying out a hydrothermal reaction, the precipitate was filtered and washed with $0.1 \mathrm{~mol} / \mathrm{L} \mathrm{HCl}$ solution and distilled water, and dried at $60^{\circ} \mathrm{C}$ overnight.

FITC-APTS (fluorescein linked (3-aminopropyl)triethoxysilane) conjugate was synthesized following the method of Santra et al. [20]. A liquid mixture was prepared by adding $1 \mathrm{~mL}$ of $\mathrm{NH}_{4} \mathrm{OH}$ to $30 \mathrm{~mL}$ of absolute ethanol, and stirred for $5 \mathrm{~min}$. Then, 1.4 $\mathrm{mL}$ of $\mathrm{NH}_{4} \mathrm{OH}, 3 \mathrm{mg}$ of $\mathrm{TiO}_{2}-\mathrm{NTs}$, and $50 \mu \mathrm{L}$ of TEOS were added, and the mixture stirred for $10 \mathrm{~min}$. After addition of $100 \mu \mathrm{L}$ of FITC-APTS conjugate, the solution was stirred for $24 \mathrm{~h}$ to complete the preparation, followed by washing, centrifugation, and dilution of the supernatant with phosphate buffered saline (PBS) to $100 \mu \mathrm{g} / \mathrm{mL}$. Finally, the resulting $\mathrm{FITC}^{-\mathrm{TiO}_{2}}$-NTs sample was sterilized and stored in the dark.

\subsection{Cell culture}

Mouse NSCs were cultured in high-glucose DMEM with $10 \%$ fetal bovine serum (Sigma), 5\% horse serum (Gibco), glutamine $(1 \mathrm{mmol} / \mathrm{L})$, penicillin $(100 \mathrm{U} / \mathrm{mL})$, and streptomycin $(100 \mu \mathrm{g} / \mathrm{mL})$. Culture dishes were placed under humidified $5 \% \mathrm{CO}_{2}$ and 
$95 \%$ air at $37^{\circ} \mathrm{C}$. Cultured stem cells were incubated with the FITC-TiO ${ }_{2}-\mathrm{NTs}$ for a predetermined period.

\subsection{AFM study}

Cell imaging was performed using an AFM (Shimadzu SPM 9600) in the contact mode. For sample preparation, the stem cells were seeded at a density of $5 \times 10^{4}$ cells $/ \mathrm{mL}$ per glass coverslip and grown for $12 \mathrm{~h}$. Then the cells were exposed to $25 \mu \mathrm{L}$ of $\mathrm{TiO}_{2}-\mathrm{NTs}(100 \mu \mathrm{g} / \mathrm{mL})$ for $12 \mathrm{~h}$ under the culture conditions. The cells were then fixed with freshly prepared and chilled $4 \%$ paraformaldehyde for $30 \mathrm{~min}$. After fixation, the cells were washed five times with chilled PBS ( $\mathrm{pH}$ 7.0) and coverslips were attached to metallic packs with double-sided conducting tape, followed by several washes with chilled PBS ( $\mathrm{pH}$ 7.0). Coverslips were blow-dried for 15 min before investigation. All phase images were recorded in the contact mode at a scanning frequency of $1.5 \mathrm{~Hz}$.

\subsection{Confocal laser scanning microscopy study}

NSCs were seeded at a density of $5 \times 10^{4}$ cells $/ \mathrm{mL}$ for $24 \mathrm{~h}$ or $48 \mathrm{~h}$ in a Petri dish specifically for the confocal study. The cells were measured with a spinning disk confocal microscope (FV-1000, Olympus) after incubation in culture medium with

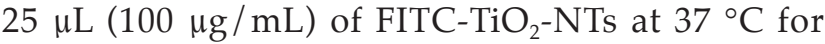
$24 \mathrm{~h}$ or $48 \mathrm{~h}$. To confirm whether the nucleus was indeed the localization site for the nanotubes, the cell nuclei were stained in blue with 4,6-diamidino2-phenylindole after $48 \mathrm{~h}$ incubation, and then the system was subject to confocal measurement.

The endocytosis pathways were investigated as follows. NSCs were plated onto $60 \mathrm{~mm}$ cell culture coverslips and cultured at $37^{\circ} \mathrm{C}$ overnight. Then cells were incubated with $75 \mu \mathrm{L}$ of $100 \mu \mathrm{g} / \mathrm{mL}$ FITC-TiO ${ }_{2}$ NTs and $175 \mu \mathrm{L}$ of $100 \mu \mathrm{g} / \mathrm{mL}$ FM4-64 in a serum-free medium at $37^{\circ} \mathrm{C}$ for $2 \mathrm{~h}$. The laser wavelengths used were: $\lambda_{\mathrm{ex}}=488 \mathrm{~nm}$ and $\lambda_{\mathrm{em}}=530 \mathrm{~nm}$ for FITC; $\lambda_{\mathrm{ex}}$ $=558 \mathrm{~nm}$ and $\lambda_{\mathrm{em}}=734 \mathrm{~nm}$ for FM4-64.

\subsection{TEM study}

NSCs were seeded at a density of $1 \times 10^{6}$ cells in a 60 $\mathrm{mm}$ tissue culture dish and grown overnight. The cells were treated with $75 \mu \mathrm{L}$ of $100 \mu \mathrm{g} / \mathrm{mL}$ FITC-
$\mathrm{TiO}_{2}-\mathrm{NTs}$ for another $48 \mathrm{~h}$. After that, they were thoroughly washed with chilled PBS, pelleted by centrifugation, and fixed with $0.1 \%$ glutaraldehyde. Cell images were recorded at $60 \mathrm{kV}$ using TEM (Philips CM 120 Holland).

\subsection{Nuclear isolation}

Nuclear isolation was performed using the KeyGen nuclei isolation kit according to the supplied protocol. The kit supplies a complete set of lysis reagents that enable the separation of nuclear extract from cultured cells. Briefly, the adherent cells were treated with pancreatic enzyme and then centrifuged at $800 \mathrm{rpm}$ for $5 \mathrm{~min}$. After estimating the packed cell volume, the appropriate amount (10 times the cell volume) of pre-chilled lysis buffer was added. The cell pellets were resuspended and reagent A (1/20th of the the cell volume) was added and the mixture subjected to vigorous vortex mixing. Cells were incubated in ice for 10-20 $\mathrm{min}$, then shocked every $30 \mathrm{~s}$ with a vortex for 3-5 min. Isolated nuclei were above $95 \%$ as observed using phase contrast microscopy. After centrifuging at $1000 \mathrm{rpm}$ for $3 \mathrm{~min}$, the cell pellets were resuspended with lysis buffer (10 times the cell volume). The mixture was then centrifuged at $1000 \mathrm{rpm}$ for $3 \mathrm{~min}$, and then resuspended with 0.5 $\mathrm{mL}$ medium buffer $\mathrm{A}$. Ice-cold medium buffer $\mathrm{B}$ was added to another clean pre-chilled tube. Cell suspensions were slowly poured into the medium buffer B. Finally, the mixture was centrifuged at $1000 \mathrm{rpm}$ for $10 \mathrm{~min}$, the supernatant was discarded and the fional product stored at $-80{ }^{\circ} \mathrm{C}$ until use. All centrifugation procedures were performed at $4{ }^{\circ} \mathrm{C}$.

\subsection{Inductively coupled plasma (ICP) study}

Mouse NSCs were seeded at a density of $1 \times 10^{6}$ cells in a $60 \mathrm{~mm}$ tissue culture dish and grown overnight. The cells were treated with $75 \mu \mathrm{L}$ of $100 \mu \mathrm{g} / \mathrm{mL}$ FITC- $\mathrm{TiO}_{2}$-NTs for another $48 \mathrm{~h}$. To determine the endocytosis mechanism of FITC-TiO $-\mathrm{NTs}$, NSCs were seeded at a density of $1 \times 10^{6}$ cells in a $60 \mathrm{~mm}$ tissue culture dish and grown overnight. The cells were treated with $75 \mu \mathrm{L}$ of $100 \mu \mathrm{g} / \mathrm{mL}$ FITC- $\mathrm{TiO}_{2}$ NTs for another $4 \mathrm{~h}$ at $37^{\circ} \mathrm{C}$ and on a parallel with $4{ }^{\circ} \mathrm{C}$. After that, they were washed with chilled PBS six times to ensure that the $\mathrm{FITC}-\mathrm{TiO}_{2}-\mathrm{NTs}$ on the 
cell surface were well cleaned. The cells were treated with pancreatic enzyme and then centrifuged at $1200 \mathrm{rpm}$ for $5 \mathrm{~min}$. The supernatant was aspirated, and the cell pellet was nitrified with aqua regia. After evaporation of the samples at $90{ }^{\circ} \mathrm{C}$ for $6 \mathrm{~h}$, the mixture was diluted with $2 \% \mathrm{HNO}_{3}$ to $10 \mathrm{~mL}$. $2 \%$ (v/v) $\mathrm{HNO}_{3}$ solution was used as the blank sample to determine the detection limit (DL). Ten parallel determinations of a sample were done with a mean of $0.0182 \mu \mathrm{g} / \mathrm{mL}$ and a standard deviation (SD) of $0.000241 \mu \mathrm{g} / \mathrm{mL}$. ICP analysis was carried out using a Prodigy ICP (Leeman Labs., USA).

\section{Results and discussion}

\subsection{Characterization of $\mathrm{TiO}_{2}-\mathrm{NTs}$}

\subsubsection{TEM and confocal imaging}

The TEM image (Fig. 1(a)) shows the shape and size of originally unmodified $\mathrm{TiO}_{2}-\mathrm{NTs}$. The confocal image
(Fig. 1(b)) shows that the FITC-TiO $-\mathrm{NTs}$ have good fluorescence intensity. The TEM image in Fig. 1(c)

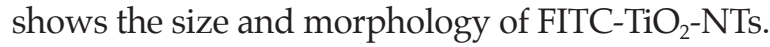

\subsubsection{X-ray diffraction (XRD)}

Figure 2 shows the XRD patterns of unmodified $\mathrm{TiO}_{2}$-NTs (Fig. 2(a)) and FITC-TiO ${ }_{2}$-NTs (Fig. 2(b)). The characteristic reflection peaks of the rutile $\mathrm{TiO}_{2}$ structure can be observed. Comparison with the standard pattern for $\mathrm{TiO}_{2}[21,22]$ shows that the the peaks can be assigned to the 110, 101, 111, 211, 220, and 301 reflections. The XRD patterns of the unmodified $\mathrm{TiO}_{2}-\mathrm{NTs}$ and $\mathrm{FITC}-\mathrm{TiO}_{2}-\mathrm{NTs}$ are similar, showing that $\mathrm{TiO}_{2}$ exists as a single rutile phase in both materials.

\subsection{Morphological changes of cell surface after incubation}

When combined with conventional tools, AFM can provide an understanding of the cellular secretion

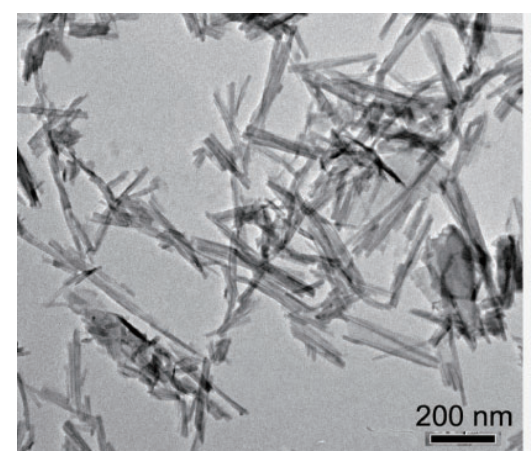

(a)

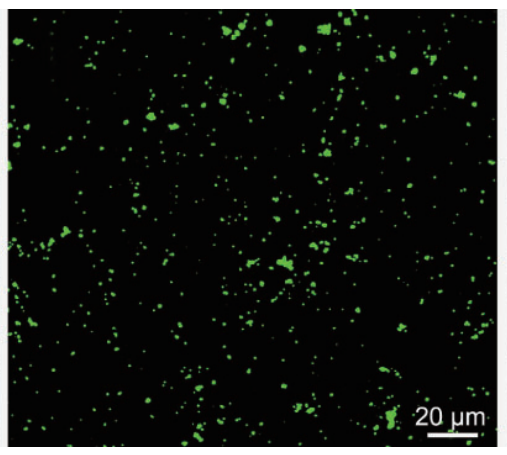

(b)

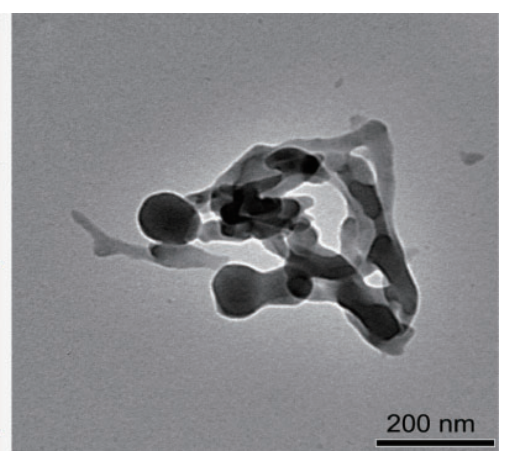

(c)

Figure 1 (a) $\mathrm{TiO}_{2}$-NTs with average diameter $<10 \mathrm{~nm}$ and length $<400 \mathrm{~nm}$; (b) confocal image of FITC-TiO $-\mathrm{NTs}$; (c) TEM image of FITC-TiO - NTS

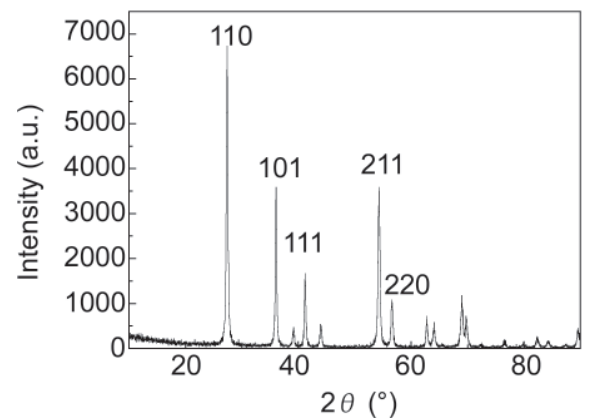

(a)

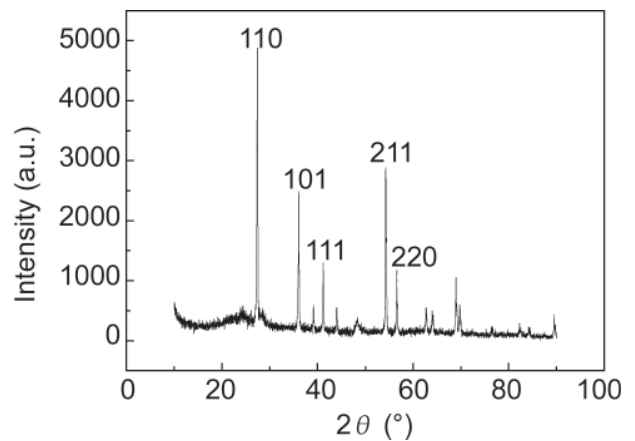

(b)

Figure 2 XRD patterns: (a) $\mathrm{TiO}_{2}-\mathrm{NTS}$; (b) FITC-TiO $-\mathrm{NTS}$ 
and membrane fusion at the molecular level [23-25]. Figs. 3(a) and 3(d) reveal that many pit-like structures (depressions) appear in the surface of the cellular membrane whilst Figs. 3(b) and 3(e) show the 3-D height plots. The depression openings range from 200 to $250 \mathrm{~nm}$ in diameter and the cone-shaped pits range from 25 to $35 \mathrm{~nm}$ in relative depth. The analysis data (Fig. 3(c)) of one depression opening (Fig. 3(a)) show its diameter to be $234 \mathrm{~nm}$ and depth $30 \mathrm{~nm}$. These

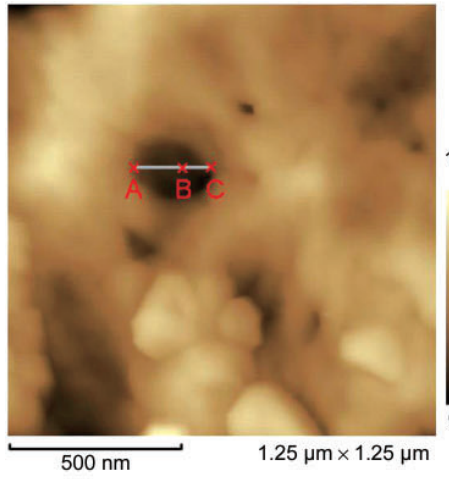

(a)

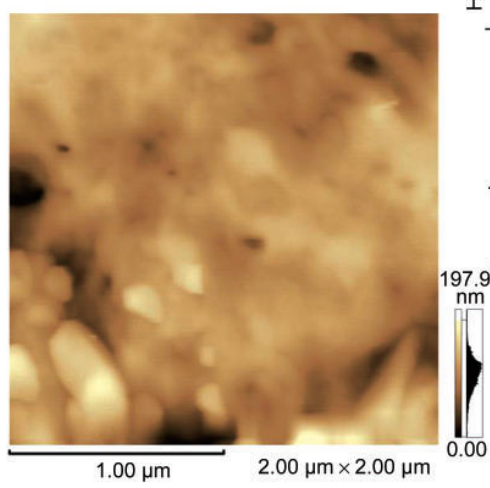

(d)

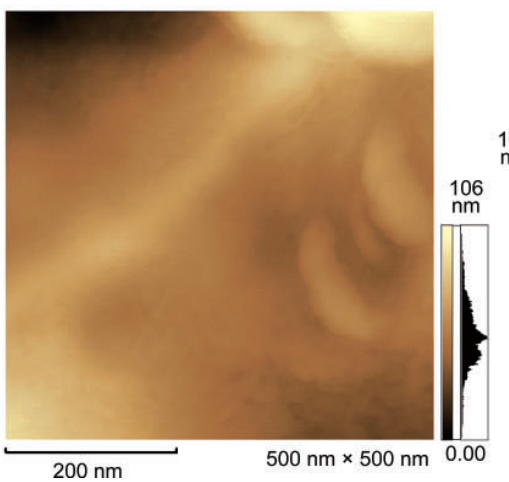

(f)

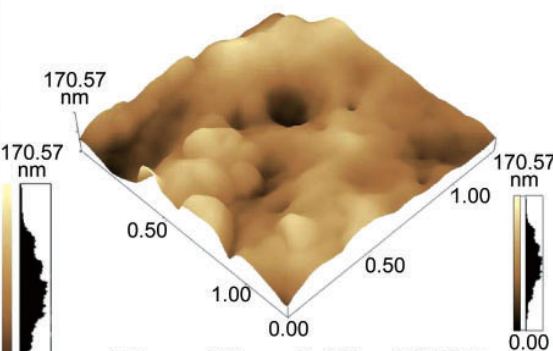

$1.25 \mu \mathrm{m} \times 1.25 \mu \mathrm{m} \quad Z 0.00-170.57 \mathrm{~nm}$

(b)

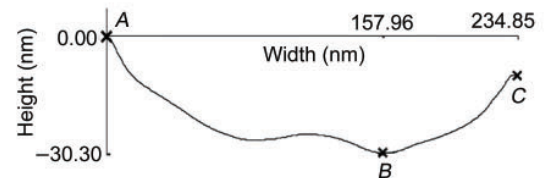

(c)

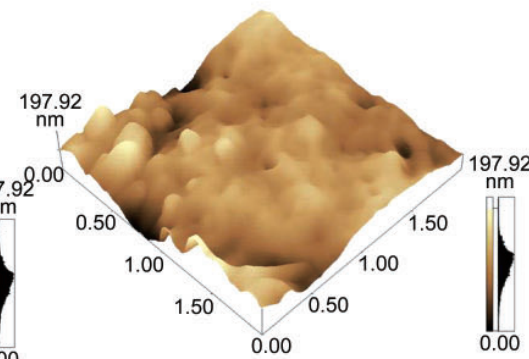

$2.00 \mu \mathrm{m} \times 2.00 \mu \mathrm{m} \quad Z \quad 0.00-197.92 \mathrm{~nm}$

(e)

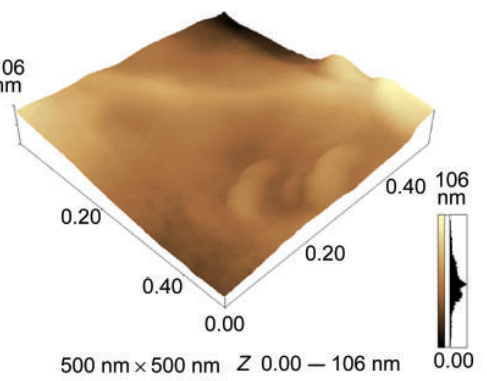

(g)
Figure 3 AFM images of the morphological change in cell surface after incubation of cells and FITC-TiO - NTs for $12 \mathrm{~h}$ : (a) and (d) are the top views of AFM images; (c) is the analysis data for (a); ( $f$ ) is a control image; (b), (e) and ( $g$ ) are the height images in 3-D for the respective panels. All images were obtained in air pits imply that the footprints remained when NPs were internalized into the cell.

\subsection{Confocal imaging of intracellular uptake and localization of NTs}

In Fig. 4, the confocal images show that FITC$\mathrm{TiO}_{2}$-NTs can be internalized into the cells after incubation for $24 \mathrm{~h}$. FITC- $-\mathrm{TiO}_{2}-\mathrm{NTs}$ localize around the cell nucleus without crossing the karyotheca. To confirm whether the nucleus was indeed the localization site for $\mathrm{TiO}_{2}$-NTs, the incubation time was prolonged to $48 \mathrm{~h}$ and the cell nucleus was stained in blue with DAPI. The exciting results, as shown in Fig. 5, demonstrate that FITC-TiO ${ }_{2}$-NTs eventually pass across the karyotheca to localize in the nucleus.

Singh et al. reported that $\mathrm{TiO}_{2} \mathrm{NPs}$ were rapidly taken up by cells, generally as membrane-bound aggregates and large intracellular aggregates in vesicles, vacuoles, and lamellar bodies, but no particles were observed inside nuclei or any other vital organelles [26]. Only a few examples have been reported of carbon

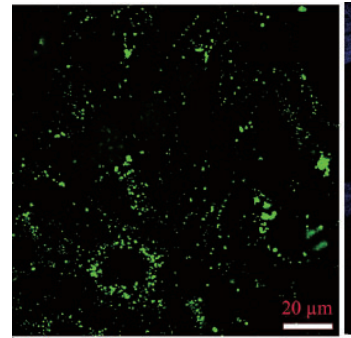

(a)

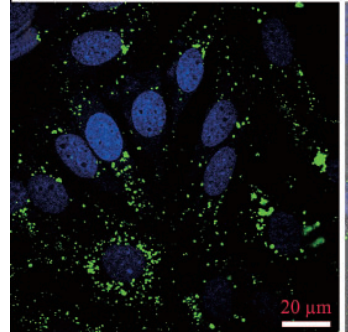

(c)

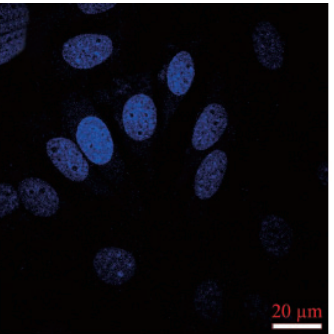

(b)

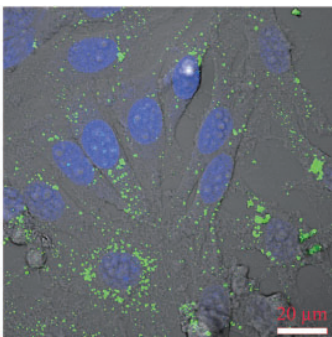

(d)
Figure 4 Confocal images of NSCs obtained after incubation for $24 \mathrm{~h}$ with FITC-TiO $-\mathrm{NTs}$ : (a) $\mathrm{FITC}_{2} \mathrm{TiO}_{2}$ NTs (green color) in NSCs; (b) nuclei stained blue with DAPI dye; (c) merger of (a) and (b); (d) merger of (c) and bright field image of NSCs. The merged images show that FITC-TiO 2 -NTs accumulate mainly in the cytoplasm 
nanotubes passing through the cell membrane and becoming located in the nucleus [27, 28]. The present results have shown that the functionalized $\mathrm{TiO}_{2}-\mathrm{NTs}$ can pass through the cell membrane and then locate inside the nuclei after long term incubation (Fig. 5). Importantly, TEM confirms further that the modified NTs are indeed present in the nucleus (Fig. 6).

\subsection{Mechanistic studies}

The cellular internalization of nanoparticles seems very complex and involves multiple endocytic mechanisms including clathrin-mediated endocytosis, caveolae-mediated endocytosis, as well as clathrin- and caveolae-independent endocytosis, rather than one single endocytic pathway. The size, coating, and molecular properties of nanoparticles and their intracellular destination, as well as the cell type, may determine the preferred endocytic pathway for their uptake [27]. Futhermore, cells may take up exogenous macromolecules by their internalization pathways, such as endocytosis, macropinocytosis or phagocytosis [29].

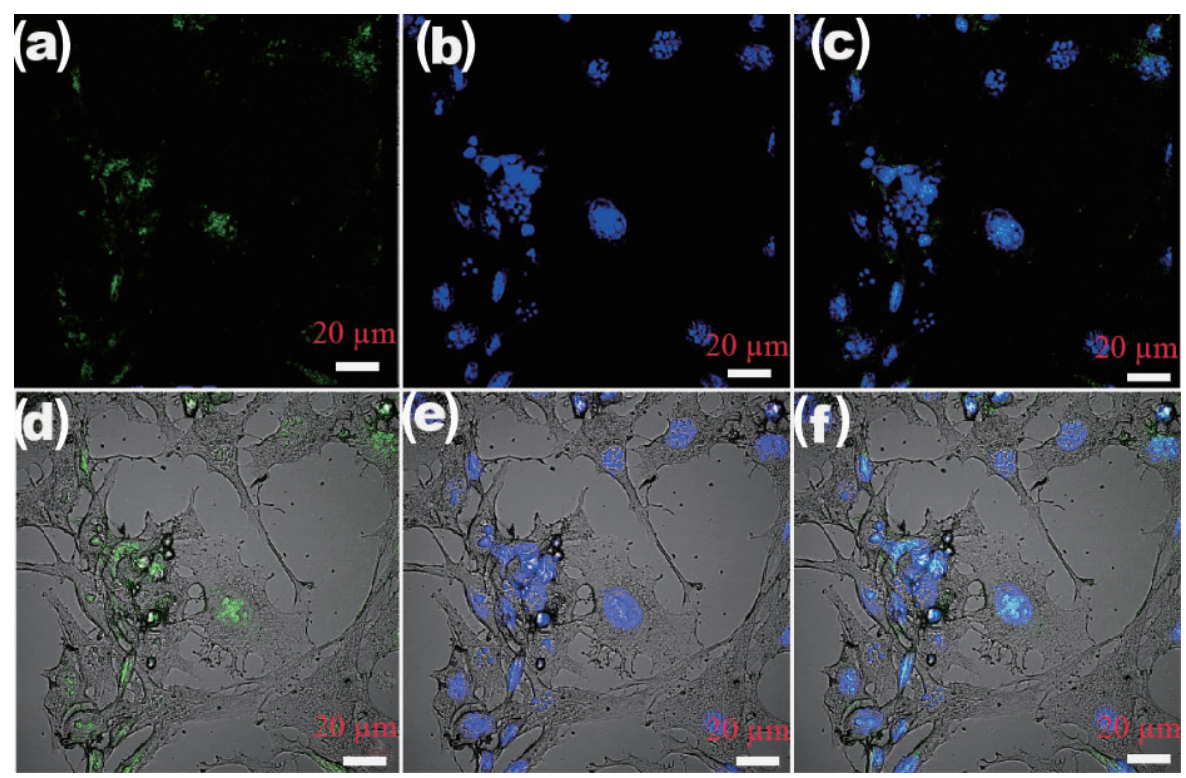

Figure 5 Confocal images of NSCs incubated with FITC-TiO ${ }_{2}-\mathrm{NTs}$ for $48 \mathrm{~h}$; (a) FITC-TiO $-\mathrm{NTs}$ (green color) in NSCs; (b) cell nuclei stained blue with DTPI dye; (c) merger of (a) and (b); (d), (e) and (f) are the merged images of (a), (b) and (c), respectively, with the bright field image of NSCs. The merged images show that $\mathrm{FITC}_{\mathrm{TiO}}$-NTs accumulate mainly in the nuclei and that NSCs grew well after co-incubation with FITC-TiO ${ }_{2}-\mathrm{NTS}$ for $48 \mathrm{~h}$

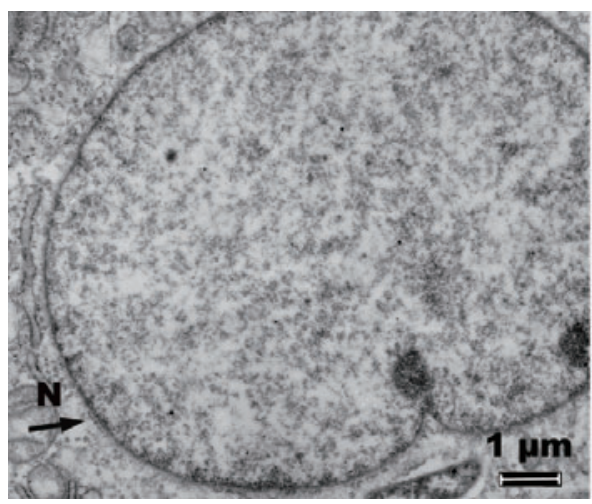

(a)

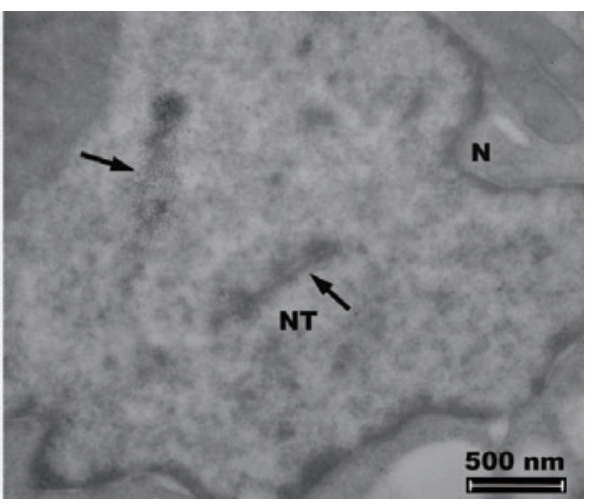

(b)

Figure 6 TEM image of NSCs after co-incubation with FITC-TiO ${ }_{2}-\mathrm{NTs}$ for $48 \mathrm{~h}$. (a) image of a control cell; (b) NTs in cell nucleus. N denotes the nuclear membrane and NT the FITC-TiO ${ }_{2}$-NTs 
To determine how many $\mathrm{TiO}_{2}-\mathrm{NTs}$ were taken up by the mouse NSCs and to confirm that FITC$\mathrm{TiO}_{2}-\mathrm{NTs}$ were located in the nucleus, elemental analysis by ICP was carried out. Table 1 shows that the cellular uptake of FITC-TiO - NTs by NSCs at $37^{\circ} \mathrm{C}$ increased continuously with increasing time. However, at $4{ }^{\circ} \mathrm{C}$, the cellular content $(0.019 \mu \mathrm{g} / \mathrm{mL})$ was near the value for the blank sample and less than the detection limit. Therefore, the cellular uptake is inhibited at $4{ }^{\circ} \mathrm{C}$, and we conclude that it involves an energy-dependent endocytosis mechanism.

In order to further investigate the cellular uptake process of FITC-TiO 2 -NTs, NSCs were co-treated with FITC- $\mathrm{TiO}_{2}$-NTs and FM4-64. Dye FM4-64 is a lipophilic styryl compound used in a variety of studies involving the plasma membrane and vesiculation [30,31] and is also used as a common membrane-selective marker for the endocytosis process. As shown in Fig. 7(c), the merged panel image clearly shows the endosome vesicles enwrapping FITC- $\mathrm{TiO}_{2}$-NTs. The co-localization of FITC- $\mathrm{TiO}_{2}$-NTs (green) and FM4-64 (red) directly reveals that the $\mathrm{FITC}-\mathrm{TiO}_{2}-\mathrm{NTs}$ are transported into cells via the endocytosis process, which is consistent with the AFM, TEM, and ICP results. This confirms that the cellular uptake process of $\mathrm{FITC}-\mathrm{TiO}_{2}-\mathrm{NTs}$ involves energy-dependent endocytosis.

In addition, NSC nuclei were isolated and purified after co-incubation with $\mathrm{FITC}-\mathrm{TiO}_{2}-\mathrm{NTs}$ at $37{ }^{\circ} \mathrm{C}$ for $48 \mathrm{~h}$, and the content of FITC- $\mathrm{TiO}_{2}-\mathrm{NTs}$ inside the nuclei was measured by ICP. As shown in Table 1, the concentration of titanium inside the nuclei is $0.113 \mu \mathrm{g} / \mathrm{mL}$, which is consistent with the confocal and TEM results shown in Figs. 5 and 6 . Although the nuclear targeting mechanism of FITC$\mathrm{TiO}_{2}-\mathrm{NTs}$ is not well known, there has been some published work showing that another typical onedimensional nanomaterial, CNTs, can cross the nuclear membrane and be retained in the nucleus [9, 32]. Cheng et al. inferred that the CNT-accumulation

Table 1 ICP results of the concentration of FITC-TiO 2 -NTs after co-incubation with NSCs for different time under different conditions

\begin{tabular}{|c|c|c|c|c|c|}
\hline Co-incubation temperature & \multicolumn{4}{|c|}{37} & 4 \\
\hline Location & \multicolumn{3}{|c|}{ In NSCs } & In nuclei & In NSCs \\
\hline Co-incubation time $(\mathrm{h})$ & 4 & 24 & 48 & 48 & 4 \\
\hline Conc. of $\mathrm{Ti}(\mu \mathrm{g} / \mathrm{mL})$ & $0.096 \pm 0.008$ & $0.174 \pm 0.009$ & $0.212 \pm 0.004$ & $0.113 \pm 0.012$ & $0.019 \pm 0.0002$ \\
\hline
\end{tabular}

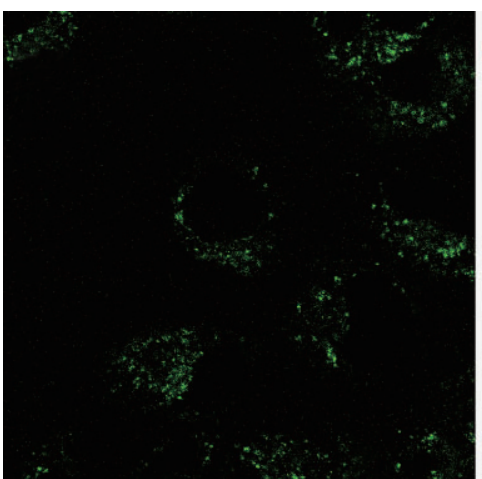

(a)

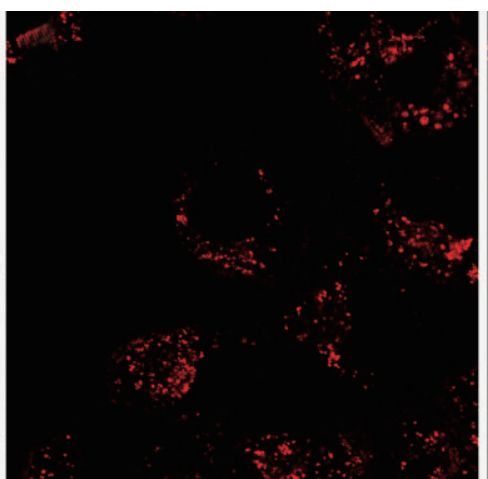

(b)

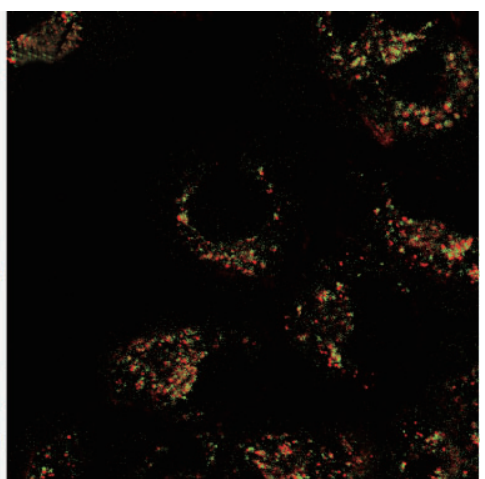

(c)

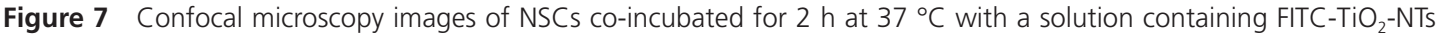
((a), green fluorescence) and the endocytosis marker FM4-64 ((b), red fluorescence). The merged image of (a) and (b) ((c), yellow fluorescence) shows that the $\mathrm{FIC}_{\mathrm{TiO}}$-NTs are co-localized with FM4-64 in the endosome vesicles, and thus the internalization of FITC-TiO $-\mathrm{NTS}$ via the endocytosis process is confirmed 
in nuclei might come from CNTs binding with specific nuclear proteins or nucleic acids [33]. In general, a nuclear pore complex (NPC), with a size range between $30 \mathrm{~nm}$ and $60 \mathrm{~nm}$, is the only known route for direct nucleocytoplasmic exchange of matter [28]. $\mathrm{TiO}_{2}-\mathrm{NTs}$ have average diameter less than $10 \mathrm{~nm}$, which facilitates penetration of $\mathrm{TiO}_{2}$ NTs into the cell nucleus through NPC. Escape from endosomal/lysosomal vesicles and accumulation in the perinuclear region is another pathway for nanoparticle transport from the cytoplasm into the cell nucleus, since this may facilitate physical contact of nanoparticles with NPCs. In fact, the confocal images have shown that FITC-TiO ${ }_{2}-\mathrm{NTs}$ predominantly accumulate in the perinuclear region of NSCs. Therefore, we infer that FITC-TiO ${ }_{2}-\mathrm{NTs}$ are internalized into nuclei through NPCs, and that some specific nuclear proteins in the cell cytoplasm may play an important role during the passage of FITC$\mathrm{TiO}_{2}$-NTs through the NPC.

The most important genetic informationDNA-concentrates in the nucleus, thus enabling some DNA-targeting drugs to kill tumor cells via DNA impairment. Oyelere et al. reported in 2007 that peptide-conjugated gold nanorods translocated into both the cytoplasm and the nucleus portion [11]. This study demonstrated the possibility that gold nanorods can be used for nuclear targeting. But, on the other hand, there have been some reports of the potential toxicity of gold nanoparticles, such as their cytotoxicity [34-37], limited biocompatibility or oxidative stress [38-40]. Given the good biocompatibility of $\mathrm{TiO}_{2}-\mathrm{NT}$, our results suggest that $\mathrm{TiO}_{2}-\mathrm{NT}$ is a good candidate as a nanovehicle for cancer drug delivery. Generally, nanotubes have significant advantages over nanoparticles as a medicine carrier. In contrast to the spherical NPs, the geometry of NTs might allow them to be multiply functionalized by different molecules that allow the nanovehicle to carry the drug more efficiently to the target $[41,42]$. For the purpose of cancer therapy, the exploration of nuclear DNA-targeting NTs carrying antitumor drugs is of particular importance. Undoubtedly, it is one of the difficult challenges in the emerging arena of cancer nanotechnology [43, 44].

\section{Conclusions}

We present a simple method for imaging intracellular $\mathrm{TiO}_{2}-\mathrm{NTs}$ using confocal microscopy and TEM. It is demonstrated for the first time that $\mathrm{TiO}_{2}$-NTs are able to cross the karyotheca and enter the nucleus. Hence, we infer that $\mathrm{TiO}_{2}$ nanotubes are promising future nanovehicles for DNA-targeting drugs in cancer therapy. We are only at the earliest stages in cancer nanotechnology and the translocation mechanism of the FITC- $\mathrm{TiO}_{2}-\mathrm{NTs}$ across the karyotheca remains to be elucidated.

\section{Acknowledgements}

This work was supported key project of the Chinese National Programs for Fundamental Research and Development Ministry of Science and Technology (973 Program) (2006CB705604), the National Natural Science Foundation (50578090), and the Shuguang Project of the Shanghai Education Committee (07SG46).

\section{References}

[1] Peer, D.; Karp, J. H.; Hong, S.; Frokhzad, O. C.; Margalit, R.; Langer, R. Nanocarriers as an emerging platform for cancer therapy. Nat. Nanotechnol. 2007, 2, 751-760.

[2] Moghimi, S. M.; Hunter, A. C.; Murray, J. C. Nanomedicine: Current status and future prospects. FASEB J. 2005, 19, 311-330.

[3] Jain, K. K. Nanotechnology in clinical laboratory diagnostics. Clin. Chim. Acta. 2005, 358, 37-54.

[4] Nie, S.; Xing, Y.; Kim, G. J.; Simons J. W. Nanotechnology applications in cancer. Annu. Rev. Biomed. Eng. 2007, 9, 257-288.

[5] Rawat, M.; Singh, D.; Saraf, S. Nanocarriers: Promising vehicle for bioactive drugs. Biol. Pharm. Bull. 2006, 29, 1790-1798.

[6] Chavanpatil, M. D.; Khdair, A.; Panyam, J. Nanoparticles for cellular drug delivery: Mechanisms and factors influencing delivery. J. Nanosci. Nanotechnol. 2006, 6, 2651-2663.

[7] Choi, M.; Katie, J. A cellular Trojan Horse for delivery of therapeutic nanoparticles into tumors. Nano Lett. 2007, 7, 3759-3765. 
[8] Loo, C.; Lowery, A.; Halas, West, N. J. ; Drezek, R. Immunotargeted nanoshells for integrated cancer imaging and therapy. Nano Lett. 2005, 5, 709-711.

[9] Pantarotto, D.; Briand, J.; Prato, M.; Bianco, A. Translocation of bioactive peptides across cell membranes by carbon nanotubes. Chem. Commun. 2004, 16-17.

[10] Porter, A. E.; Gass, M.; Muller, K.; Skepper, J. N.; Midgley, P. A.; Welland, M. Direct imaging of single-walled carbon nanotubes in cells. Nat. Nanotechnol. 2007, 2, 713-717.

[11] Oyelere, A. K.; Chen, P. C.; Huang, X.; El-Sayed, I. H.; El-Sayed, M. A. Peptide-conjugated gold nanorods for nuclear targeting. Bioconjugate Chem. 2007, 18, 14901497.

[12] Roy, S. C.; Paulose, M.; Grimes, C. A. The effect of $\mathrm{TiO}_{2}$ nanotubes in the enhancement of blood clotting for the control of hemorrhage. Biomaterials 2007, 28, $4667-$ 4672.

[13] Cooper, L. F.; Zhou, Y.; Takebe, J.; Guo, J.; Abron, A.; Holme'n, A.; Ellingsen, J. E. Fluoride modification effects on osteoblast behavior and bone formation at $\mathrm{TiO}_{2}$ gritblasted c.p. titanium endosseous implants. Biomaterials 2006, 27, 926-936.

[14] Kommireddy, D. S.; Sriram, S. M.; Lvov, Y. M.; Mills, D. K. Stem cell attachment to layer-by-layer assembled $\mathrm{TiO}_{2}$ nanoparticle thin films. Biomaterials 2006, 27, 42964303

[15] Sanchez, C.; Julian, B.; Belleville, P.; Popall, M. Applications of hybrid organic-inorganic nanocomposites. J. Mater. Chem. 2005, 15, 3559-3592.

[16] Guzman, R.; Uchida, N.; Bliss, T. M.; He, D.; Christopherson, K. K.; Stellwagen, D. Long-term monitoring of transplanted human neural stem cells in developmental and pathological contexts with MRI. Proc. Natl. Acad. Sci. USA 2007, 104, 10211-10216.

[17] Kasuga, T.; Hiramatsu, M.; Hoson, A.; Sekino, T.; Niihara, $K$. Formation of titanium oxide nanotube. Langmuir 1998, 14, 3160-3163

[18] Kasuga,T.; Hiramatsu, M.; Hoson, A.; Sekino, T.; Niihara, K. Titania nanotubes prepared by chemical processing. Adv. Mater. 1999, 11, 1307-1311.

[19] Kasuga, T. Formation of titanium oxide nanotubes using chemical treatments and their characteristic properties. Thin Solid Films 2006, 496, 141-145.

[20] Santra, S.; Liesenfeld, B.; Bertolino, C.; Dutta, D.; Cao, Z.; Tan, W.; Moudgil, B. M.; Mericle, R. A. Fluorescence lifetime measurements to determine the core-shell nanostructure of FITC-doped silica nanoparticles: An optical approach to evaluate nanoparticle photostability. J. Lumin. 2006, 117, 75-82.

[21] Qu, Y.; Li, X.; Li, R.; Yan, H.; Ouyang, X.; Wang, X. Preparation and characterization of the $\mathrm{TiO}_{2}$ ultrafine particles by detonation method. Mater. Res. Bull. 2008, 43, 97-103.

[22] Li, X.; Qu,Y.; Sun, G.; Jiang, D.; Ouyang, X. Study on the lattice distortion of the as-prepared nanosized $\mathrm{TiO}_{2}$ particles via detonation method. J. Phys. Chem. Solids 2007, 68, 2405-2410.

[23] Jena, B. P. Cell secretion machinery: Studies using the AFM. Ultramicroscopy 2006, 106, 663-669.

[24] Jeremic, A.; Kelly, M.; Cho, W. J.; Cho, S. J.; Horber, J. K. H.; Jena, B. P. Calcium drives fusion of SNARE-apposed bilayers. Cell Biol. Int. 2004, 28, 19-31.

[25] Binnig, G.; Quate, C. F.; Gerber, C. H. Atomic force microscope. Phys. Rev. Lett. 1986, 56, 930-933.

[26] Singh, S.; Shi, T.; Duffin, R.; Albrecht, C.; Van Berlo, D.; Höhr, D. Endocytosis, oxidative stress and IL-8 expression in human lung epithelial cells upon treatment with fine and ultrafine $\mathrm{TiO}_{2}$ : Role of the specific surface area and of surface methylation of the particles. Toxicol. Appl. Pharmacol. 2007, 222, 141-151.

[27] Chen, M.; Mikecz, A. Uptake and cytotoxity of nanoparticles. In Nanotoxicology; Zhao, Y.; Nalwa, H. S., Eds.; American Scientific Publishers : California, 2007, pp. 75-90.

[28] Fuente, J. M.; Berry, C. C. Tat peptide as an efficient molecule to translocate gold nanoparticles into the cell nucleus. Bioconjugate Chem. 2005, 16, 1176-1180.

[29] Khine, M.; Lau, A.; Ionescu-Zanetti, C.; Seo, J.; Lee, L. P. A single cell electroporation chip. Lab. Chip 2005, 5, 3843

[30] Morris, M. C.; Depollier, J.; Mery, J.; Heitz, F.; Divita, G. A peptide carrier for the delivery of biologically active proteins into mammalian cells. Nat. Biotechnol. 2001, 19, 1173-1176.

[31] Li, W.; Chen, C.; Ye, C.; Wei, T.; Zhao, Y.; Lao, F.; Chen, Z.; Meng, H.; Gao,Y.; Yuan, H. The translocation of fullerenic nanoparticles into lysosome via the pathway of clathrin-mediated endocytosis. Nanotechnology 2008, 19, 145102.

[32] Pantarotto, D.; Singh, R.; McCarthy, D.; Erhardt, M.; Briand, J. P.; Prato, M.; Kostarelos, K.; Bianco, A. Functionalized carbon nanotubes for plasmid DNA gene 
delivery. Angew. Chem. Int. Ed. 2004, 43, 5242-5246.

[33] Cheng, J.; Shiral Fernando, K. A.; Monica Veca, L.; Sun, Y.; Lamond, A.; Lam, Y.; Cheng, S. Reversible accumulation of PEGylated single-walled carbon nanotubes in the mammalian nucleus. ACS Nano 2008, 2, 2085-2094.

[34] Bhattacharya, R.; Mukherjee, P.; Xiong, Z.; Atala, A.; Soker, S.; Mukhopadhyay, D. Gold nanoparticles inhibit VEGF165-induced proliferation of HUVEC cells. Nano Lett. 2004, 4, 2479-2481.

[35] Shukla, R.; Bansal, V.; Chaudhary, M.; Basu, A.; Bhonde, R. R.; Sastry, M. Biocompatibility of gold nanoparticles and their endocytotic fate inside the cellular compartment: A microscopic overview. Langmuir 2005, 21, 10644-10654.

[36] Pan, Y.; Neuss, S.; Leifert, A.; Fischler, M.; Wen, F.; Simon, U.; Schmid, G.; Brandau, W.; Jahnen-Dechent, W. Size-dependent cytotoxicity of gold nanoparticles. Small 2007, 3, 1941-1949.

[37] Male, K. B.; Lachance, B.; Hrapovic, S.; Sunahara, G.; Luong, J. H. T. Assessment of cytotoxicity of quantum dots and gold nanoparticles using cell-based impedance spectroscopy. Anal. Chem. 2008, 80, 5487-5493.
[38] Shi, X.; Wang, S.; Sun, H.; Baker, J. R. Jr. Improved biocompatibility of surface functionalized dendrimerentrapped gold nanoparticles. Soft Matter 2007, 3, 71-74.

[39] Li, J. J.; Zou, L.; Hartono, D.; Ong, C. N.; Bay, B. H.; Yung, L. Y. L. Gold nanoparticles induce oxidative damage in lung fibroblasts in vitro. Adv. Mater. 2008, 20, 138-142.

[40] Jia, H.Y.; Liu, Y.; Zhang, X. J.; Han, L.; Du, L.B.; Tian, Q.; $X u, Y . C$. Potential oxidative stress of gold nanoparticles by induced-NO releasing in serum. J. Am. Chem. Soc. 2009, 131, 40-41.

[41] Suh, W. H.; Suh, Y.; Stucky, G. D. Multifunctional nanosystems at the interface of physical and life sciences. Nano Today 2009, 4, 27-36.

[42] Popat, K. C.; Eltgroth, M. T.; Tempa, J.; Grimes, C. A.; Desai, T. A. Titania nanotubes: A novel platform for drug-eluting coatings for medical implants? Small 2007, 3, 1878-1881.

[43] Park,T. G.; Jeong, J. H.; Kim, S. W. Current status of polymeric gene delivery systems. Adv. Drug. Deliv. Rev. 2006, 58, 467-486.

[44] Wang, Z.; Zhao, Y.; Ren, L.; Jin, L.; Sun, L.; Yin, P.; Zhang, Y.; Zhang, Q. Novel gelatin-siloxane nanoparticles decorated by Tat peptide as vectors for gene therapy Nanotechnology 2008, 19, 445103. 